\title{
Superficial peroneal nerve entrapment neuropathy and role of pulsed radiofrequency neuromodulation
}

\author{
Yüzeyel peroneal sinir tuzak nöropatisi ve pulse radyofrekans nöromodülasyonunun rolü
}

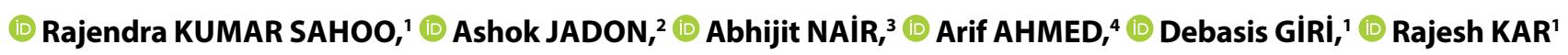

\begin{abstract}
Summary
Peripheral neuropathy secondary to entrapment of the nerves is not an uncommon etiology. Nerve entrapment is a common occurrence following trauma or surgery and poses significant diagnostic challenge. Entrapment neuropathy (EN) may not respond to standard neuropathic medication and may need invasive treatment. Pulsed radiofrequency (PRF) application is a recent modality and is gaining popularity for many EN as it does not cause neural ablation unlike conventional radiofrequency ablation. In this report, we present a case of young patient who presented with severe lower lateral leg pain in whom superficial peroneal nerve (SPN) EN was suspected and diagnostic SPN injection under ultrasound guidance confirmed the diagnosis. He subsequently underwent PRF neuromodulation and experienced long-lasting pain relief.
\end{abstract}

Keywords: Chronic pain; diagnostic injection; entrapment neuropathy; leg pain; neuropathic pain; neuropathy; pulsed radiofrequency; sonography; superficial peroneal nerve; ultrasound.

\begin{abstract}
Özet
Tuzak nöropatisine sekonder periferik nöropati nadir görülen bir durum değildir. Tuzak nöropatisi, travma veya cerrahiyi takiben sık görülen bir durumdur ve önemli bir tanısal zorluk teşkil eder. Tuzak nöropatisi (TN) standart nöropatik ilaçlara yanıt vermeyebilir ve invaziv tedavi gerektirebilir. Pulse radyofrekans (PRF) uygulaması yeni bir modalitedir ve geleneksel radyofrekans ablasyonundan farklı olarak nöral ablasyona neden olmadığı için birçok TN'nde popülerlik kazanmaktadır. Bu yazıda, şiddetli alt lateral bacak ağrısı ile başvuran, yüzeyel peroneal sinir (YPN) TN'nden şüphelenilen ve ultrason eşliğinde tanısal YPN enjeksiyonu ile tanısı doğrulayan genç bir hasta sunulmaktadır. Pulse radyofrekans nöromodülasyonu yapılan hasta, ağrısı uzun süreli rahatladı.

Anahtar sözcükler: Bacak ağrıs; kronik ağrl; nöropati; nöropatik ağrl; pulse radyofrekans; sonografi; tanısal enjeksiyon; tuzak nöropati; ultrason; yüzeysel peroneal sinir.
\end{abstract}

\section{Introduction}

Peripheral neuropathies are relatively common clinical conditions which may be classified as compressive, or entrapment and non-compressive neuropathies. Nerve entrapment is considered when there is compression of a nerve as it passes through an anatomic structure, most commonly a fibro-osseous tunnel or fascial opening. ${ }^{[1]}$ Common peroneal nerve (CPN) entrapment is a common entrapment neuropathy (EN) of lower extremity because of its location but superficial peroneal nerve EN (SPNEN) is a relatively rare cause of entrapment. In a study of nearly 500 patients with chronic leg pain, it was found that only $3.5 \%$ had entrapment of the SPN. ${ }^{[2]}$ SPN arises from CPN at the level of fibular neck and descends in the lateral compartment of the leg. In the mid-to-distal third of the leg, SPN is sandwiched between peroneus brevis and extensor digitorum longus and the intermuscular septum which separates the anterior and lateral compartments of leg. The nerve is below the crural fascia (CF) at this location and gradually ascends into a superficial location before eventually piercing the CF approximately 10

\footnotetext{
'Department of Anesthesiology and Pain Management, HealthWorld Hospitals, Durgapur, India

${ }^{2}$ Department of Anesthesia and Pain Relief, Tata Motors Hospital, Jharkhand, India

${ }^{3}$ Department of Anesthesia, Basavatarakam Indo-American Cancer Hospital and Research Institute, Hyderabad, India

${ }^{4}$ Department of Anesthesia, Queens Hospital, London, United Kingdom

Submitted: 25.06.2020 Accepted after revision: 10.01.2021 Available online date: 13.01.2021
}

Correspondence: Dr. Rajendra Kumar Sahoo. Department of Anesthesiology and Pain Management, HealthWorld Hospitals, Durgapur, India. 
$\mathrm{cm}$ proximal to the lateral malleolus. ${ }^{[3]}$ One of the common sites of SPN entrapment is the place where nerve pierces the CF to become superficial; however, this is variable. ${ }^{[4]}$ Localized trauma or injury of the limb is the common cause SPN entrapment. Other causes include repeated ankle sprain, overstretching of the leg from repetitive activity, ankle arthroscopy, hypertrophy of peroneal muscles, and peroneal exertional syndrome.

\section{Case Report}

A 33-year-old man presented to our pain clinic with 10 months history of severe pain over his right lateral mid-to-distal leg. He had a superficial cut injury over the affected leg around 1 year back which was sutured. He attributed that injury as a trigger for pain. His pain became severe for the past 6 weeks which he described as sharp, burning, tingling, and stabbing in nature. On a numerical rating scale (NRS: 0 meaning no pain and 10 meaning worst imaginable pain), he described his average pain to be 6 , whereas worst pain as 9 which occurs on walking.

On physical examination, he located the healed cut injury area as the source of pain with significant tenderness and hyperalgesia over that area. He described radiating tingling pain up to lower lateral leg on pressing that area. There were no color or hair changes, sweating, and trophic changes with intact sensory and motor function. A bedside ultrasound (US) examination revealed a swollen SPN just below the $\mathrm{CF}$ and probe pressure elicited pain. We made a diagnosis of SPNEN and put him on a short course of tramadol $37.5 \mathrm{mg}$ with acetaminophen $325 \mathrm{mg}$ combination 3 times daily and gabapentin $300 \mathrm{mg}$ at bedtime with slow titration by $300 \mathrm{mg}$ every $5-7$ days till a dose of $1200-1800 \mathrm{mg}$ in three divided doses or as tolerated.

The patient returned to us in 2 weeks time with persistent pain as medication provided around $30 \%$ relief, but he experienced dizziness from gabapentin. We planned a diagnostic block and hydrodissection of SPN under US guidance after an informed consent. A linear high frequency probe was used (MTurbo, Sonosite, Fujifilm Sonosite India) and $21 \mathrm{G} 5 \mathrm{~cm}$ needle (Stimuplex ${ }^{\oplus 60}$, B Braun Melsungen AG, Germany) was inserted from posterior to anterior targeting the SPN below CF (Fig. 1). The nerve was hydrodissected

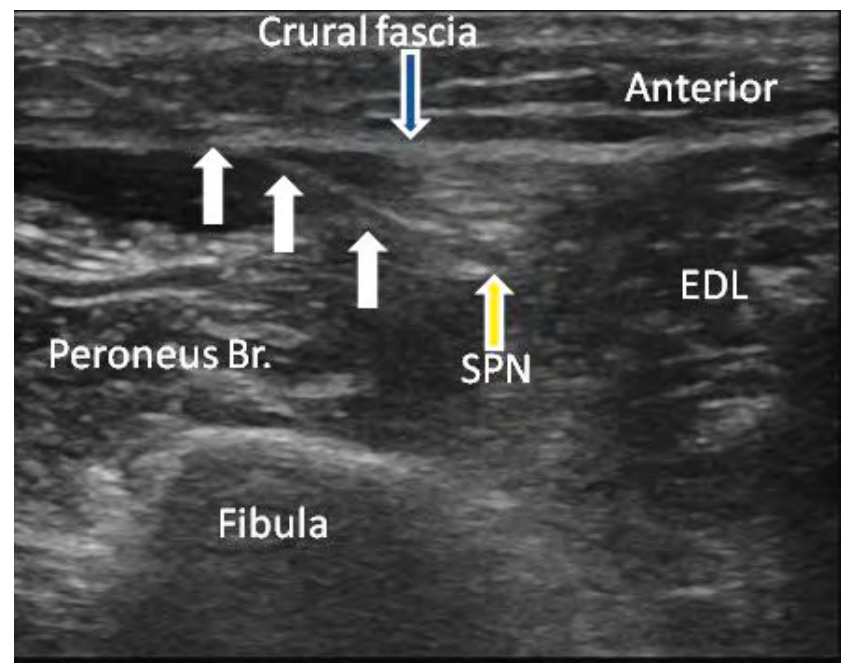

Figure 1. Sonoanatomy of mid-to-distal lateral leg showing the relevant structures for diagnostic injection of SPN with in-plane needle insertion (white bold arrows) tip just below the nerve.

SPN: Superficial peroneal nerve; Peroneus Br: Peroneus Brevis; EDL: Extensor digitorum longus.

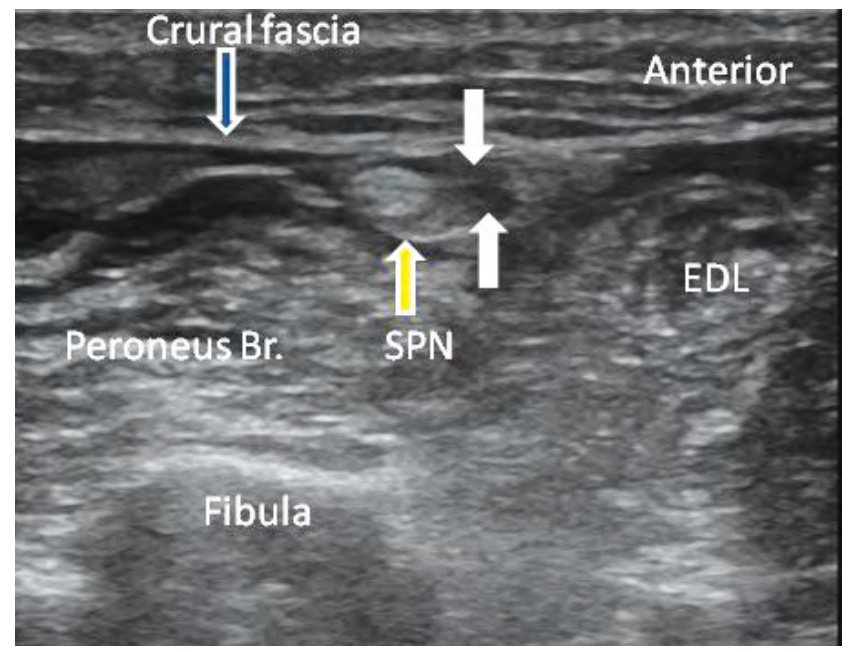

Figure 2. Sonoanatomy following diagnostic block and hydrodissection. White bold arrow shows injectant surrounding the superficial peroneal nerve marked by yellow bold arrow.

SPN: Superficial peroneal nerve; Peroneus Br: Peroneus Brevis; EDL: Extensor digitorum longus.

from fascia using $4 \mathrm{ml}$ of $2 \%$ lidocaine, $4 \mathrm{ml}$ normal saline, and $40 \mathrm{mg}$ methylprednisolone acetate (Fig. 2). The patient reported complete pain relief after the procedure which lasted for around 3 weeks. As pain returned back to baseline by 1 month, we planned for pulsed radiofrequency (PRF) neuromodulation of SPN. This time under US guidance, a $10 \mathrm{~cm}$ RF cannula with $10 \mathrm{~mm}$ active tip (Cosman Medical, LLC, Burlington MA, USA) was inserted targeting the top of the nerve. Sensory stimulation was done at $50 \mathrm{~Hz}$ when the patient reported concordant pain and paresthesia at 0.4 volt. Following that PRF was done at $42^{\circ}$ for 6 min and another cycle of PRF below the nerve. At the end, we injected $4 \mathrm{ml} 1 \%$ lidocaine 
with $40 \mathrm{mg}$ methylprednisolone acetate. The procedure was uneventful and the patient did not report any immediate complication. We followed him at 1 , 3 , and 6 months interval where he reported around $80 \%$ pain relief and better quality of life.

\section{Discussion}

Clinical presentation of SPNEN is variable, depending on the site of entrapment. Classically, pain is localized to the mid-to-distal third of the lateral leg with radiation to the dorsum of the foot. Night pain and pain at rest are not uncommon, although symptoms are commonly aggravated by activity. Most of the times, local examination of the foot reveals no specific motor weakness or sensory loss. Although deep palpation of the nerve at the site of exit at CF may lead to positive Tinel's sign, this is not true in all patients. ${ }^{[1]}$

SPNEN is mainly diagnosed on the basis of clinical symptoms. Often electrodiagnostic studies help in detecting the abnormalities in conduction velocity, latency, and amplitude and aid in diagnosis. However, neuromuscular US in recent times has helped to accurately locate the nerves, and the site of impingement as the nerves is bigger just proximal to the entrapment. US also helps in accurately depositing local anesthetic (LA) and/or steroid in the vicinity of the nerve, which is often considered as a diagnostic and therapeutic intervention in $\mathrm{EN}^{[5-7]}$

There is lack of guidelines on management of EN. Earlier surgical decompression or neurolysis was done in patients who had failed conservative treatment. However, in recent times, US-guided injections, hydrodissection, and PRF are being increasingly done. ${ }^{[7,8]}$ PRF is a recent treatment modality with good benefit in occipital, post-herpetic, and inguinal neuralgia. ${ }^{[9]}$ SPN PRF has been reported to provide pain relief in mechanical allodynia in CRPS patients which was even resistant to lumbar sympathetic neurolysis. ${ }^{[10]}$

\section{Conclusion}

In conclusion, we present a case of severe pain from SPNEN which finally got relieved with PRF. Bedside US looking for possible entrapment, and diagnostic LA and/or steroid injection helps in confirming the diagnosis and planning for future treatment.

Informed Consent: Written informed consent was obtained from the patient for the publication of the case report and the accompanying images.

Conflict-of-interest issues regarding the authorship or article: None declared.

Peer-rewiew: Externally peer-reviewed.

\section{References}

1. Flanigan RM, DiGiovanni BF. Peripheral nerve entrapments of the lower leg, ankle, and foot. Foot Ankle Clin 2011;16:255-74. [CrossRef]

2. Styf J, Morberg P. The superficial peroneal tunnel syndrome. Results of treatment by decompression. J Bone Joint Surg Br 1997;79:801-3. [CrossRef]

3. Chin KJ. Ultrasound visualization of the superficial peroneal nerve in the mid-calf. Anesthesiology 2013;118:956-65.

4. Matsumoto J, Isu T, Kim K, Iwamoto N, Yamazaki K, Isobe M. Clinical features and surgical treatment of superficial peroneal nerve entrapment neuropathy. Neurol Med Chir (Tokyo) 2018;58:320-5. [CrossRef]

5. Chang KV, Mezian K, Naňka O, Wu WT, Lou YM, Wang JC, et al. Ultrasound imaging for the cutaneous nerves of the extremities and relevant entrapment syndromes: From anatomy to clinical implications. J Clin Med 2018;7:457.

6. Norbury JW, Nazarian LN. Ultrasound-guided treatment of peripheral entrapment mononeuropathies. Muscle Nerve 2019;60:222-31. [CrossRef]

7. Chang KV, Wu WT, Özçakar L. Ultrasound imaging and guidance in peripheral nerve entrapment: Hydrodissection highlighted. Pain Manag 2020;10:97-106. [CrossRef]

8. Byrd D, Mackey S. Pulsed radiofrequency for chronic pain. Curr Pain Headache Rep 2008;12:37-41. [CrossRef]

9. Chang MC. Efficacy of Pulsed radiofrequency stimulation in patients with peripheral neuropathic pain: A narrative review. Pain Physician 2018;21:E225-34. [CrossRef]

10. Chae WS, Kim SH, Cho SH, Lee JH, Lee MS. Reduction in mechanical allodynia in complex regional pain syndrome patients with ultrasound-guided pulsed radiofrequency treatment of the superficial peroneal nerve. Korean J Pain 2016;29:266-9. [CrossRef] 